\title{
RISK FACTORS FOR HEPATOCELLULAR CARCINOMA
}

\author{
Marilena Stoian, Victor Stoica \\ dr Ion Cantacuzino Hospital, Bucharest
}

\begin{abstract}
Hepatocellular carcinoma (HCC), the third leading cause of cancer deaths worldwide, with incidence rising is expected to increase by another $81 \%$ by the year 2020 , primarily due to the hepatitis $C$ epidemic. The strongest risk factors for the development of HCC is a hepatitis $B$ (HBV) and hepatitis C (HCV) virus infection, as well as cirrhosis of any cause. Other risk factors that have been reported include exposure to aflatoxin, alcohol, tobacco, obesity and diabetes. To detect potentially curable cases of hepatocellular carcinoma, outpatients with chronic liver disease who have been seen at the Dr. Ion Cantacuzino Hospital, since 10 years and examined periodically with real-time ultrasonography and measurement of serum alpha-fetoprotein. We analyzed the data on these patients for risk factors for hepatocellular carcinoma.

The risk of liver cancer in men was 1.33 times higher than in women; patients in their 60s had significantly higher rate ratios (6.46) than patients in their 40s; patients with liver cirrhosis diagnosed at enrollment had significantly higher rate ratios for liver cancer (1.93) than patients with chronic hepatitis. The high serum alpha-fetoprotein level at enrollment was also confirmed as a significant marker for a high risk, regardless of the stage of disease (chronic hepatitis or liver cirrhosis). The serum markers for hepatitis virus -- HBsAg, and anti-HCV were significantly associated with the risk of liver cancer: the adjusted rate ratios for HBsAg, anti-HBC, and anti-HCV were estimated to be 6.92, 4.54, and 4.09, respectively. Hepatitis $B$ surface antigen (rate ratio 6,92; 95\% Cl: 2.92 to 16.39) and hepatitis C antibody (rate ratio 4.09; $95 \% \mathrm{Cl}: 1.30$ to 12.85 ) showed the most risk for carcinoma.

Further studies are required to clarify the roles of other risk factors, including drinking and smoking habits.
\end{abstract}

Keywords: hepatocellular carcinoma, risk factors; serum alpha-fetoprotein, hepatitis $B$ surface antigen, hepatitis C antibody.

\section{Rezumat}

Carcinomul hepatocelular (HCC) reprezintă a treia cauză de decese prin cancer la nivel mondial, iar incidența acestuia este de așteptat să crească cu încă 81 \% până în 2020, în primul rând ca urmare epidemiei de hepatită C. Cel mai important factor de risc pentru dezvoltarea HCC este infecția cu virus hepatitic $B(V H B)$ și virus hepatitic $C(V H C)$, precum și ciroza de orice cauză. Alți factori de risc care au fost raportați includ expunerea la aflatoxină, consumul de 


\section{INTEH}

alcool, fumatul, obezitatea și diabetul. Pentru a detecta cazuri potențial curative de carcinom hepatocelular, pacienții cu afecțiuni hepatice cronice urmăriți ambulator la Spitalul Dr. Cantacuzino, au fost examinați periodic prin ultrasonografie și măsurarea alfa-fetoproteinei serice, pentru un interval de 10 ani.

Au fost analizate datele referitoare la factorii de risc pentru carcinomul hepatocelular. Riscul de cancer la ficat a fost de 1,33 ori mai mare la bărbați decât la femei; pacienții cu vârsta de 60 de ani aveau rate de rate semnificativ mai mari $(6,46)$ decât pacienții în vârstă de 40 de ani; pacienții diagnosticați la înrolare cu ciroză hepatică au prezentat rate semnificativ mai mari pentru cancerul hepatic $(1,93)$ decât pacienții cu hepatită cronică. Nivelul crescut al alfafetoproteinei serice la înscrierea în studiu a fost, de asemenea, confirmat ca un marker semnificativ de risc ridicat, indiferent de stadiul bolii (hepatită cronică sau ciroză hepatică). Markerii serici pentru virusurile hepatitice- HBsAg și anti-HCV - au fost semnificativ asociați cu riscul de cancer hepatic: ratele ajustate de risc pentru AgHBs, anti-HBC și anti-HCV au fost estimate la 6,92, 4,54, respectiv 4,09. Antigenul de suprafață al virusului hepatitic $B$ (rata de risc 6,92; 95\% Cl: 2, 92 - 16,39) și anticorpii anti VHC (rata de risc 4,09; 95\% Cl: 1,30 - 12,85) au reprezentat cei mai importanți factori de risc pentru carcinom.

Sunt necesare studii suplimentare pentru a clarifica rolurile altor factori de risc, inclusiv consumul de băuturi alcoolice și fumatul.

Cuvinte cheie: carcinom hepatocelular, factori de risc, alfa-fetoproteina serică, Ag HBs, Ac anti VHC. 


\section{Background}

Hepatocellular carcinoma (HCC) is now the third leading cause of cancer deaths worldwide, with over 500,000 people affected, while hepatocellular carcinoma was the fifth most common causes of cancer deaths worldwide ${ }^{(1)}$ in 2005. In the United States and Europe the incidence of HCC is rising, and is expected to increase by another $81 \%$ by the year 2020 , primarily due to the hepatitis $\mathrm{Cepidemic}^{(2)}$.

The strongest risk factors for the development of HCC is a hepatitis B (HBV) and hepatitis $C$ (HCV) virus infection, as well as cirrhosis of any cause ${ }^{(3)}$. Other risk factors that have been reported include exposure to aflatoxin $^{(4)}$, alcohol, tobacco, obesity ${ }^{(5)}$ and diabetes ${ }^{(6)}$. Hepatocellular carcinoma has been well documented to cluster within families ${ }^{(7,8)}$, but this has been primarily in regions where $\mathrm{HBV}$ is endemic and may have been related to a high prevalence of chronic HBV infection in those families. Only one case-control study of family history and HCC has been performed in an area with a low prevalence of HBV, involving 287 cases and 450 controls in northern Italy ${ }^{(9)}$.

A family history of cancer of any type did not appear to increase the risk of having HCC, suggesting a genetic defect specific for the liver rather than mutation of a widely expressed tumor suppressor gene such as p53 $3^{(10)}$ or DNA synthesis gene such as thymidylate synthase ${ }^{(11)}$.

Having a sibling with HCC appear to confer a much higher risk than having a parent with $\mathrm{HCC}$ suggesting the possibility of a recessive inheritance pattern. While these two observations seem to support a role for genetic factors, it is also possible than environmental factors, e.g. dietary habits or exposure to carcinogens such as aflatoxin may contribute to familial clustering of HCC. Cirrhosis due to non-alcoholic fatty liver disease (NAFLD) is becoming an increasingly important cause of $\mathrm{HCC}^{(12)}$. Numerous studies have shown that risk factors for NAFLD such as obesity, diabetes and dyslipidemia run in the family, possibly due to a combination of genetic factors and shared lifestyle. With increasing prevalence of obesity and NAFLD in the United States and world-wide, future studies should determine if family history of NAFLD, diabetes or metabolic syndrome is a risk factor for development of HCC.

Family history of liver cancer is a risk factor for HCC in men but not in women; HCC in men is associated with shorter CAG repeats in the androgen receptor gene, but HCC in women is conversely associated with longer CAG repeats $^{(13)}$. Hormonal differences may account for the higher incidence of HCC in men; clearly, gender differences in the genetics of HCC are an important area for further study.

To detect potentially curable cases of hepatocellular carcinoma, outpatients with chronic liver disease who have been seen at the Dr. Ion Cantacuzino Hospital have been registered from May 2008 to June 2018 and examined periodically with real-time ultrasonography and measurement of serum alpha-fetoprotein. We analyzed the data on these patients for risk factors for hepatocellular carcinoma.

\section{Matherial and methods}

\section{Enrollment and Follow-up}

Outpatients meeting the following criteria were enrolled in the study: (1) A clinical diagnosis of chronic hepatitis or compensated cirrhosis (without ascites or jaundice, or a history of bleeding esophageal varices) during the period May 2008 through 


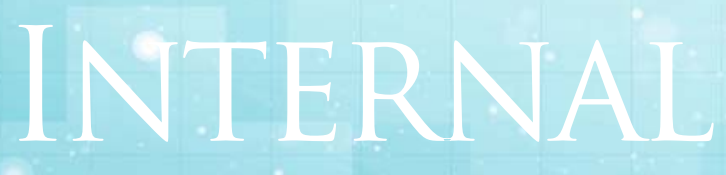

Original papers

June 2018; (2) A serum total bilirubin level of $2.0 \mathrm{mg}$ per deciliter or less ( $34 \mu \mathrm{mol}$ per liter) and a serum albumin level of $3.0 \mathrm{~g}$ per deciliter or more; (3) Age of 40 to 69 years; (4) No history of liver cancer or evidence of this disease at enrollment (patients in whom liver cancer was detected at the initial examinations or diagnosed within three months after enrollment were excluded); (5) No serious diseases; (6) Consent from both the patient and physician.

Among the registered patients, those with chronic hepatitis and an elevated serum alpha-fetoprotein concentration ( $\geq 20 \mathrm{ng}$ per milliliter) and those with liver cirrhosis were scheduled to undergo both ultrasonography and alpha-fetoprotein measurement at three-month intervals. Patients with chronic hepatitis and normal alpha-fetoprotein concentrations at enrollment were scheduled to undergo both tests at six-month intervals; the interval between examinations was reduced to three months if their alphafetoprotein concentrations increased to 20 ng per milliliter or more or if the clinical stage of the disease progressed to cirrhosis.

\section{Serologic Evaluation}

Routine serum biochemical tests were carried out with automated techniques. Hepatitis B surface antigen (HBsAg) was detected by reversed passive hemagglutination and hepatitis $B$ core antibody (anti-HBc) by enzyme immunoassay. If a serum sample was positive for anti-HBc, a 200-fold dilution of the sample was retested for the antibody. If the percentage of inhibition in the diluted sample was $\geq 90$ percent, the titer for anti$\mathrm{HBC}$ was considered high. These tests were performed in all patients at enrollment. Hepatitis C antibody (anti-HCV, C100-3 antibody) was detected by enzyme-linked immunosorbent assay (ELISA). This test became available in April 1990; in a majority of the patients, testing for anti-HCV was performed during the follow-up period, and before the date of diagnosis of liver cancer, although not at enrollment.

Alpha-fetoprotein was periodically measured by latex photometric immunoassay (normal, $<20 \mathrm{ng}$ per milliliter). Alpha-fetoprotein (AFP) is a glycoprotein that is produced in early fetal life by the liver and by a variety of tumors including hepatocellular carcinoma, hepatoblastoma and nonseminomatous germ cell tumors of the ovary and testis (eg, yolk sac and embryonic carcinoma). Most studies report elevated AFP concentrations in approximately $70 \%$ of patients with hepatocellular carcinoma. Elevated AFP concentrations are found in $50 \%$ to $70 \%$ of patients with nonseminomatous testicular tumors. AFP is elevated during pregnancy. Persistence of AFP in the mother following birth is a rare hereditary condition. Neonates 
have markedly elevated AFP levels ( $>100,000 \mathrm{ng} / \mathrm{mL}$ ) that rapidly fall to below $100 \mathrm{ng} / \mathrm{mL}$ by 150 days and gradually return to normal over their first year. Concentrations of AFP above the reference range also have been found in serum of patients with benign liver disease (e.g., viral hepatitis, cirrhosis), gastrointestinal tract tumors and, along with carcinoembryonic antigen in ataxia telangiectasia. The biological half-life of AFP is approximately 5 days.

Reference values are $<6.0 \mathrm{ng} / \mathrm{mL}$. Reference values are for no pregnant subjects only; fetal production of AFP elevates values in pregnant women. Range for newborns is not available, but concentrations over 100 $\mathrm{ng} / \mathrm{mL}$ have been reported in normal newborns, and the values rapidly decline in the first 6 months of life.

Serum markers are not specific for malignancy, and values may vary by method. Alpha-fetoprotein (AFP) levels may be elevated in association with a variety of malignancies or benign diseases. Failure of the AFP value to return to normal by approximately 1 month after surgery suggests the presence of residual tumor. Elevation of AFP after remission suggests tumor recurrence; however, tumors originally producing AFP may recur without an increase in AFP. This assay is intended only as an adjunct in the diagnosis and monitoring of alpha-fetoprotein (AFP) producing tumors. The diagnosis should be confirmed by other tests or procedures. AFP is not recommended as a screening procedure for cancer detection in the general population.

\section{Lifestyle Habits and Medical History}

Information about cigarette smoking, alcohol drinking, the medical history, and family history of liver cancer was obtained at the time of enrollment through interviews by experienced public health doctors, using a medical questionnaire.

\section{Diagnosis of Liver Cancer}

Space-occupying lesions detected or suspected at the time of ultrasonography or alpha-fetoprotein measurement were further examined with computed tomography, fineneedle aspiration biopsy ${ }^{(14)}$, and other clinical diagnostic techniques such as hepatic scintigraphy, unless the ultrasonographic findings confirmed that the lesions were unquestionably benign (e.g., hemangiomas or cysts). A final diagnosis of hepatocellular carcinoma was based on histologic findings in resected hepatic tumors or biopsy specimens.

In spite of great efforts to prevent patients from dropping out of the study, some withdrew because they were transferred to other hospitals, declined to undergo the periodic examinations, or moved from the Bucharest area.

\section{Histological Evaluation of the Liver}

The specimens of liver tissue were fixed in 10 percent formalin and routinely stained with hematoxylin and eosin. Hepatocellular carcinoma was diagnosed according to internationally accepted criteria, on the basis of the existence of a pattern of invasive growth or replacing growth ${ }^{(15)}$. Nodular lesions with none of these abnormal features were defined as large regenerative nodules ${ }^{(16)}$.

A histological diagnosis of regenerative nodules was considered confirmed if there were no distinctive changes between a nodule and the extranodular tissue. The diagnosis was considered further validated if the size of the nodule remained stable throughout clinical 


\section{INTERNAL}

\section{Original papers}

follow-up. The carcinoma was histological typed according to the classification of the World Health Organization ${ }^{(17)}$.

\section{Statistical Analysis}

The method of Kaplan and Meier ${ }^{(18)}$ was used to estimate the cumulative risk of liver cancer according to the clinical stage of liver disease at enrollment. Cox proportional-hazards regression analysis ${ }^{(19)}$ was performed to estimate rate ratios for possible risk factors for liver cancer. The period of observation used in calculating the risk of liver cancer began at the date of enrollment and ended at the date of diagnosis of liver cancer, the date of death. All reported $p$ values are two-tailed.

\section{Results}

\section{Characteristics at Enrollment}

Therese is the basic characteristics of the patients at enrollment (Table 1):

1. a total of 917 patients met the study criteria and were registered: 240 had clinically diagnosed cirrhosis of the liver, and 677 had chronic hepatitis;

2. serum alpha-fetoprotein levels were elevated in 214 patients at initial examination ( $\geq 20 \mathrm{ng}$ per milliliter);

3. HBsAg was detected in 80 of the 917 patients (8.7 percent), and anti-HBc was present in high titers in 56 patients (6.1 percent);
4. Anti-HCV was detected in 433 of the 731 patients (59.2 percent) tested for the antibody;

5. the proportion of patients under the age of 50 years was much smaller among the women than the men ( 2.3 percent vs. 20.8 percent); otherwise, the distributions of age as well as the other factors listed in Table 1 were similar with respect to sex

Table 2 hows distributions of patients according to their medical histories and lifestyle habits as recorded during interviews at enrollment:

- two hundred eleven patients had a history of blood transfusions; 53 of these patients had a history of posttransfusion hepatitis;

- fifty-six patients had a family history of liver cancer in parents, siblings, or children;

- the male patients differed from the female patients in their smoking and drinking habits: 48.2 percent of the men were current smokers and 39.0 percent were current daily drinkers, whereas 10.6 percent of the women were smokers and 6.2 percent were drinkers;

- the base-line characteristics of the 917 patients, including their medical histories and lifestyle habits, were 


\begin{tabular}{|c|c|c|c|}
\hline Characteristics & $\begin{array}{c}\text { Men } \\
(n=548)\end{array}$ & $\begin{array}{c}\text { Women } \\
\text { (N=369) }\end{array}$ & $\begin{array}{c}\text { Total } \\
(\mathrm{N}=917)\end{array}$ \\
\hline \multicolumn{4}{|l|}{ Age (year) } \\
\hline $40-49$ & $115(21.0)$ & $8(2.2)$ & $123(13.4)$ \\
\hline $50-59$ & $268(48.9)$ & $208(56.4)$ & $476(51.9)$ \\
\hline $60-69$ & $165(30.1)$ & $153(41.5)$ & $318(34.7)$ \\
\hline \multicolumn{4}{|l|}{ Stage of disease } \\
\hline Liver cirrhosis & $134(24.5)$ & $106(28.7)$ & $240(26.2)$ \\
\hline Chronic hepatitis & $414(75.5)$ & $263(71.3)$ & $677(73.8)$ \\
\hline \multicolumn{4}{|l|}{ Alpha-fetoprotein level* } \\
\hline$\geq 100 \mathrm{ng} / \mathrm{ml}$ & $20(3.6)$ & $33(8.9)$ & $53(5.8)$ \\
\hline $20-99 \mathrm{ng} / \mathrm{ml}$ & $88(16.1)$ & $73(19.8)$ & $161(17.6)$ \\
\hline Normal (<20 ng/ml) & $440(80.3)$ & $263(71.3)$ & $703(76.7)$ \\
\hline \multicolumn{4}{|l|}{ Hepatitis virus markets } \\
\hline \multicolumn{4}{|l|}{ HBsAg } \\
\hline Positive & $53(9.7)$ & $27(7.3)$ & $80(8.7)$ \\
\hline Negative & $495(90.3)$ & $342(92.7)$ & $837(91.3)$ \\
\hline \multicolumn{4}{|l|}{ Anti-HBc } \\
\hline High titer & $39(7.1)$ & $17(4.6)$ & $56(6.1)$ \\
\hline Low titer & $257(46.9)$ & $149(40.4)$ & $406(44.3)$ \\
\hline Negative & $252(46.0)$ & $203(55.0)$ & $455(49.6)$ \\
\hline \multicolumn{4}{|l|}{ Anti-HCV } \\
\hline Positive & $256(46.7)$ & $177(48.0)$ & $433(47.2)$ \\
\hline Negative & $185(33.3)$ & $113(30.6)$ & $298(32.5)$ \\
\hline Unknown status & $107(19.5)$ & $79(21.4)$ & $136(20.3)$ \\
\hline
\end{tabular}

*To convert values to grams per liter, divide by 1000 
INTERNAL

Original papers

compared with those of 215 patients who dropped out of the study before the end of the follow-up period: no remarkable differences were observed between the groups except in the prevalence of a family history of liver cancer (2.3 percent vs. 6.1 percent).

\section{Development of Liver Cancer}

During the follow-up period (from enrollment to the end of June 2018, a mean [ \pm SD] duration of $35.7 \pm 13.0$ months; range, 5 to 52), liver cancer developed in 54 patients. Hepatocellular carcinoma was diagnosed during the study in 29 patients on histological examination. Liver cancer was diagnosed post mortem in 5 patients during a follow-up study of deaths among the 215 patients who had dropped out. Three of these five patients died of liver cancer with cirrhosis of the liver, and two died of liver cancer with chronic hepatitis.

Of the 54 patients with liver cancer, 28 were found to have liver cirrhosis at enrollment and the other 26 were found to have chronic hepatitis. Ten of the 26 patients with chronic hepatitis had elevated alpha-fetoprotein levels at enrollment.

Of 54 patients whose tumors were detected by ultrasound scanning, 39 (71 percent) had unifocal disease and 15 (28 percent) had multimodal disease. In 35 patients (63 percent) the tumors were localized in the right lobe of the liver; in 5 (9 percent), in the left lobe; and in 14 (28 percent), in both lobes. Sixteen of the 40 unifocal tumors were $3 \mathrm{~cm}$ or less in diameter (so-called small tumors).

Table 3 shows the main ultrasonographic features of the tumors found either during the base-line investigation or during followup. Although it may appear that more multifocal tumors and fewer small unifocal tumors were found during follow-up, the differences were not statistically significant.

\section{III.Cumulative Risk of Liver Cancer}

Figure 1 shows Kaplan-Meier estimates of the cumulative risk of liver cancer, according to the stage of liver disease and the serum alpha-fetoprotein level at enrollment. The three-year cumulative risk $( \pm \mathrm{SE})$ of liver cancer was $12.5 \pm 2.5$ percent among the 240 patients with liver cirrhosis diagnosed at enrollment, and $3.8 \pm 0.8$ percent among the 677 with chronic hepatitis.

A log-rank test of the two curves showed a significant difference between these groups $(P<0.001)$. Among the patients with chronic hepatitis, those who had an elevated alphafetoprotein level at enrollment were at significantly higher risk for liver cancer than those who had a normal level $(P<0.001$ by log-rank test); the three-year cumulative risk was $10.2 \pm 2.7$ percent in the former and 2.9 \pm 0.8 percent in the latter. 


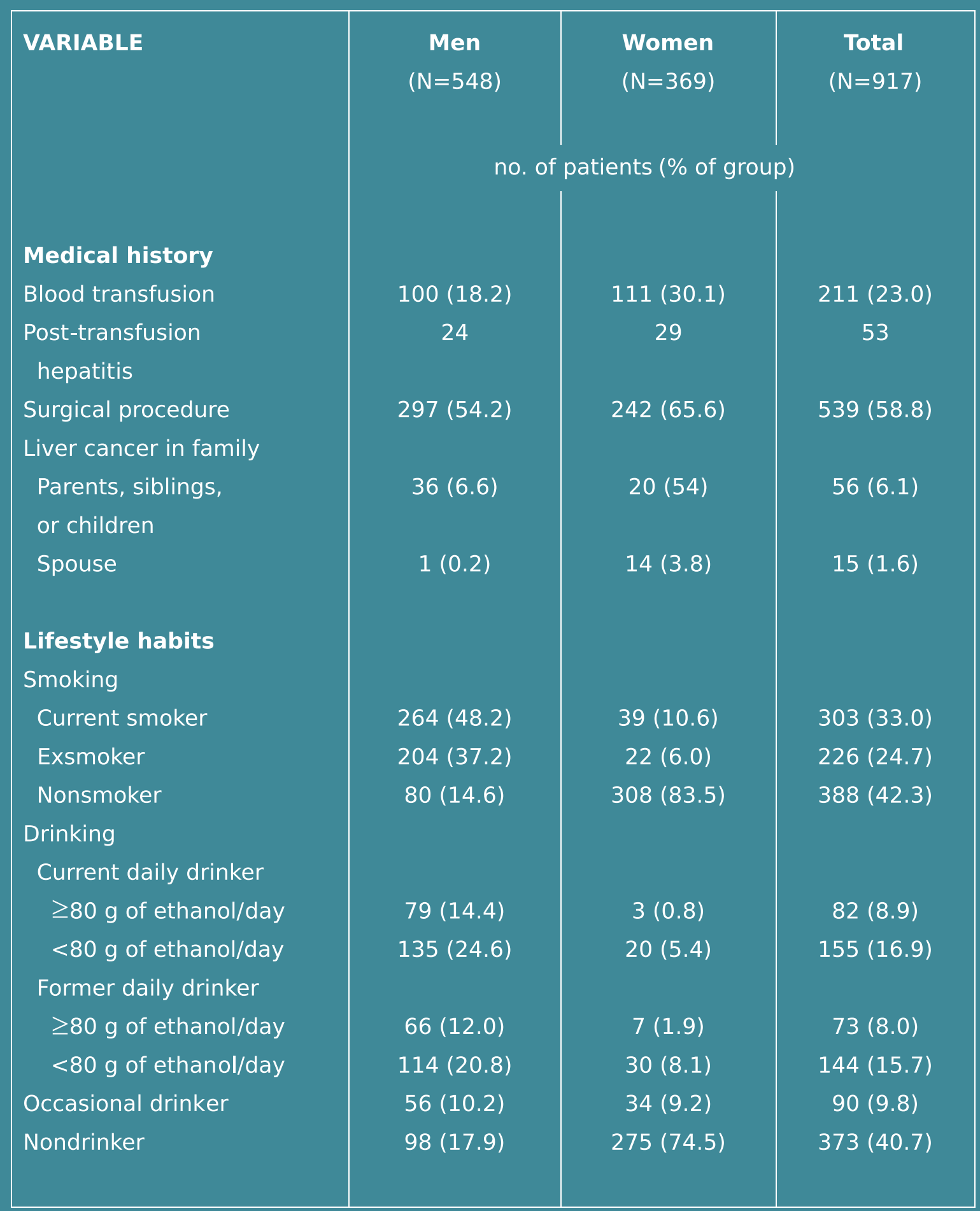




\section{INTERNAL MEDICINE}

Original papers

\begin{tabular}{|c|cc|cc|}
\hline Characteristics & \multicolumn{2}{|c|}{ At enrollment } & \multicolumn{2}{c|}{ During follow-up } \\
\hline & No & $\%$ & No & $\%$ \\
\hline Multifocal & 5 & 17 & 11 & 42 \\
\hline Unifocal & 25 & 83 & 15 & 58 \\
\hline Less 3cm & 7 & 28 & 9 & 40 \\
\hline More 3 cm & 18 & 72 & 6 & \\
\hline
\end{tabular}

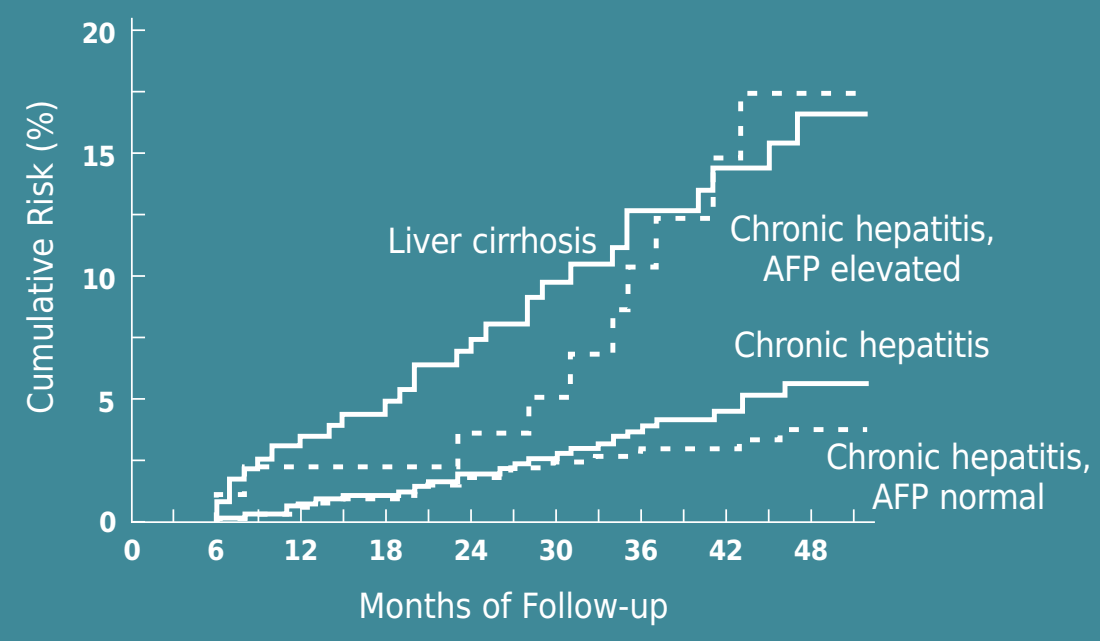

Patients at Risk

Liver cirrhosis

$\begin{array}{lllllllll}240 & 238 & 224 & 198 & 173 & 145 & 115 & 93 & 60\end{array}$

Chronic hepatitis

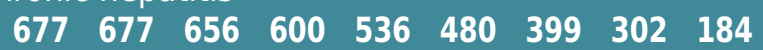

Table 3. Ultrasonographic Characteristics of Tumors

Figure 1. Cumulative Risk of Liver Cancer in 917 Patients with Chronic Liver Disease, According to the Clinical Stage of Disease at Enrollment 


\section{Hazard Rate Ratios for Liver Cancer}

Table 4 shows the results of Cox proportionalhazards regression analyses in which age, sex, and other possible confounders (stage of disease, serum alpha-fetoprotein levels, hepatitis virus markers, and drinking and smoking habits) were adjusted for simultaneously to estimate hazard rate ratios for the development of liver cancer.

The risk of liver cancer in men was 1.33 times that in women, but the difference was not significant. A positive association was observed between the risk of liver cancer and age at enrollment. Patients in their 60 s had significantly higher rate ratios (6.46) than patients in their 40s. The chi-square value for the linear trend between age at enrollment and the risk of liver cancer was significant $(P=$ 0.004). The stage of disease constituted an independent risk factor for liver cancer after adjustment for possible confounders. Patients with liver cirrhosis diagnosed at enrollment had significantly higher rate ratios for liver cancer (1.93) than patients with chronic hepatitis. The serum alpha-fetoprotein level at enrollment was also confirmed as a significant marker for a high risk, regardless of the stage of disease (chronic hepatitis or liver cirrhosis). Each of the serum markers for hepatitis virus HBsAg, and anti-HCV - was significantly associated with the risk of liver cancer.

The adjusted rate ratios for $\mathrm{HBsAg}$, anti-HBc, and anti-HCV were estimated to be $6.92,4.54$, and 4.09 , respectively. Patients whose status for anti-HCV was unknown appeared to have an elevated risk of liver cancer, but this finding was considered an artifact. Since 11 patients who had liver cancer before April 2016 left the study before the test for anti-HCV became available at our institutions, their status for anti-HCV necessarily remained unknown.

Smoking and drinking were also possible risk factors for liver cancer, since many case- control studies ${ }^{(20,21,22,23,24)}$ and a few cohort studies $^{(25,26)}$ have indicated a relation between these lifestyle factors and the risk of liver cancer. The risks in current smokers and exsmokers were, respectively, 2.30 and 1.68 times the risk in nonsmokers, although these differences were not significant. The chisquare value for the linear trend between smoking and the risk of liver cancer approached significance $(P=0.07)$. Associations between drinking and the risk of liver cancer were not so evident, as shown by the adjusted rate ratios for drinking categories.

Relations between smoking and drinking habits and the risk of liver cancer were further analyzed according to the clinical stage of liver disease at enrollment. Among the patients with liver cirrhosis, the adjusted rate ratios for current smokers and exsmokers increased to 7.96 and 3.44, respectively (chi-square for linear trend, 8.617; $P=0.003)$; the rate ratio was 1.32 for current heavy drinkers $(P=0.75)$ and 3.75 for former heavy drinkers $(P=0.04)$. Among the patients with chronic hepatitis, there were no significant associations between these lifestyle factors and the risk of liver cancer. A medical history of blood transfusions, post-transfusion hepatitis, or surgical procedures was not significantly associated with the risk of liver cancer (rate ratios after adjustment for age and sex, 1.24, 1.18 , and 1.26, respectively).

A history of liver cancer in a parent, sibling, or child or in a spouse showed a tendency toward an association with the risk of liver cancer (rate ratios after adjustment for age and sex, 1.93 and 2.66, respectively), but was not a significant risk factor.

\section{Conclusions}

Statistical data confirm that hepatocellular carcinoma (HCC) is now the third leading cause 


\section{INTERNAL}

\section{Original papers}

of cancer deaths worldwide, with over 500,000 people affected, while hepatocellular carcinoma was the fifth most common causes of cancer deaths worldwide in 2005. In the United States and Europe the incidence of HCC is rising, and is expected to increase by another $81 \%$ by the year 2020 primarily due to the hepatitis $C$ epidemic. Our study analyzed the data on patients for risk factors for hepatocellular carcinoma.

The risk of liver cancer in men was 1.33 times that in women, but the difference was not significant. A positive association was observed between the risk of liver cancer and age at enrollment. Patients in their 60 s had significantly higher rate ratios (6.46) than patients in their 40s. Patients with liver cirrhosis diagnosed at enrollment had significantly higher rate ratios for liver cancer (1.93) than patients with chronic hepatitis.

The high serum alpha-fetoprotein level at enrollment was also confirmed as a significant marker for a high risk, regardless of the stage of disease (chronic hepatitis or liver cirrhosis). The serum markers for hepatitis virus - HBsAg, and anti-HCV - were significantly associated with the risk of liver cancer: the adjusted rate ratios for HBsAg, anti-HBC, and anti-HCV were estimated to be $6.92,4.54$, and 4.09, respectively. The risks in current smokers and exsmokers were, respectively, 2.30 and 1.68 times the risk in nonsmokers, although these differences were not significant. Associations between drinking and the risk of liver cancer were not so evident.

A medical history of blood transfusions, posttransfusion hepatitis, or surgical procedures was not significantly associated with the risk of liver cancer (rate ratios after adjustment for age and sex, 1.24, 1.18, and 1.26, respectively). A history of liver cancer in a parent, sibling, or child or in a spouse showed a tendency toward an association with the risk of liver cancer (rate ratios after adjustment for age and sex, 1.93 and 2.66, respectively), but was not a significant risk factor. The ten-year cumulative risk of liver cancer was $12.5 \%$ for 240 patients with liver cirrhosis at enrollment and $3.8 \%$ for 677 patients with chronic hepatitis. Hepatitis B surface antigen (rate ratio 6,$92 ; 95 \% \mathrm{Cl}: 2.92$ to 16.39 ) and hepatitis $\mathrm{C}$ antibody (rate ratio $4.09 ; 95 \% \mathrm{Cl}: 1.30$ to 12.85) showed the most risk for carcinoma.

Further studies are required to clarify the roles of other risk factors, including drinking and smoking habits.

\section{References}

1. Bosch FX, Ribes J, Cleries R,Diaz M. Epidemiology of hepatocellular carcinoma.Clin Liver Dis 2005;9;191-211

2. El-Serag HB, Davila JA. Petersen NJ, McGlynn KA.The continuing increase in the incidence of hepatocellular carcinoma in the United States: an update.Amn Intern Med 2003; 139:817-823

3. Bruix J, Sherman M. Management of hepatocellular carcinoma. Hepatology 2005; 42;1208-1236

4. Mazzaranti R, Gramantieri L, Bolondi L. Hepatocellulr carcinima epidemiology and clinical aspects. Mod aspects 


VARIABLE
Sex
Male
Female
Age (year)**
$60-69$
$50-59$
$40-49$

Stage of disease

Liver cirrhosis

Chronic hepatitis

Alpha-fetoprotein level***

$\geq 100 \mathrm{ng} / \mathrm{ml}$

$20-99 \mathrm{ng} / \mathrm{ml}$

Normal $(<20 \mathrm{ng} / \mathrm{ml})$

HBsAg

Positive

Negative

Anti-HBC

High titer

Low titer

Negative

Anti-HCV

Positive

Unknown status

Negative

Smoking****

Current smoker

Exsmoker

Nonsmoker

Drinking

Current daily drinker $\geq 80 \mathrm{~g}$ of ethanol/day $<80 \mathrm{~g}$ of ethanol/day

Former daily drinker $\geq 80 \mathrm{~g}$ of ethanol/day $<80 \mathrm{~g}$ of ethanol/day

Occasional drinker

Non drinker

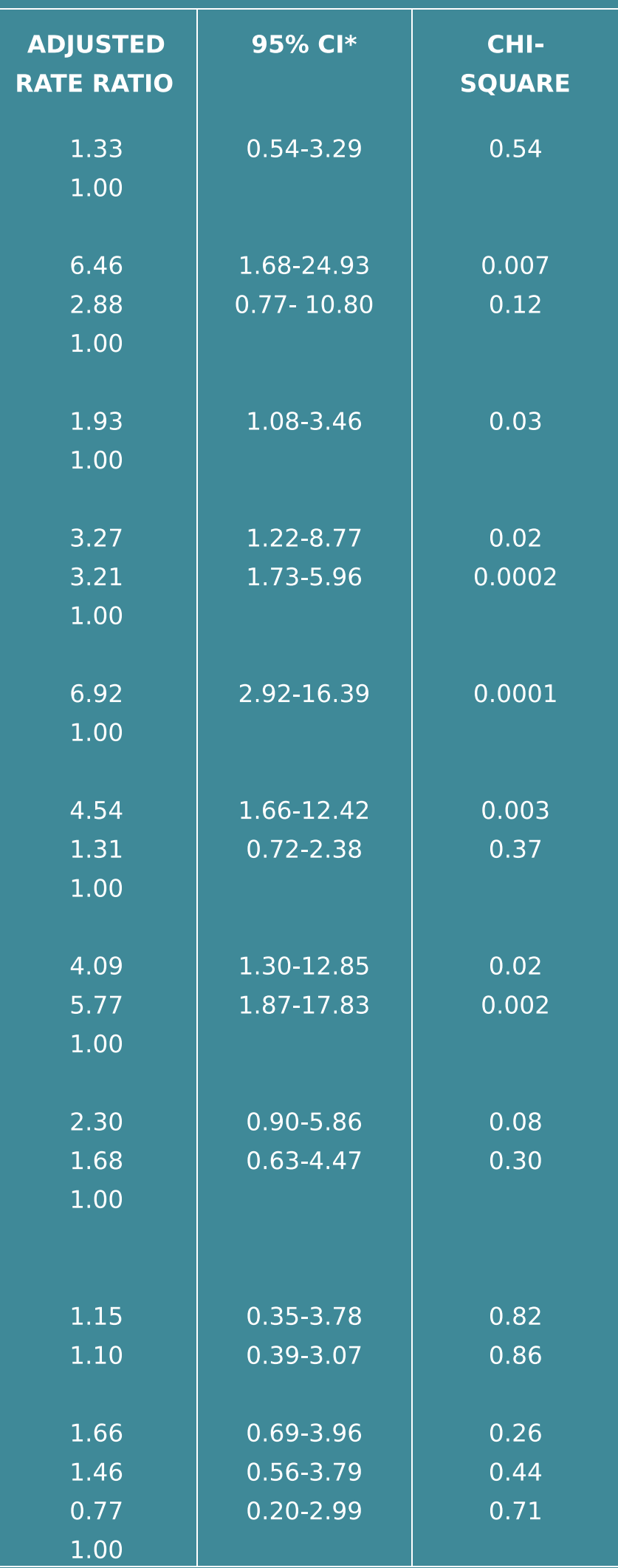

*Cl denotes confidence interval.

**Chi-square for the linear trend was $12.715(P=0.004)$

***To convert values to grarns per liter, divide by 1000 ****Chi-square for the linear trend was $3.194(P=0.07)$

Table 4. Results of Cox Proportional-Hazards Regression, Adjusted for Age, Sex, and Other Potential Confounders. 


\section{INTERNAL}

Original papers

Med 2008; 29:130-143

5. Marreto JA, Fontana RJ, Fu S.Alcohol, tobacco and obesity are synergistic risk factors for hepatocellular carcinoma. J. Hepatol 2005; 42:218-224

6. El-Serag HB, TranT, EverhartJE.Diabetes increases the risk of chronic liver disease and hepatocellular carcinoma.Gastroenterology 2004; 126: 460-468

7. Yu MW, Chang HC, Liaw YF, Lin SM, Lee SD, Lin CJ et al. Familial risk of hepatocellular carcinoma among chronic hepatitis B carriers and their relatives. J Natl Cancer Inst 2000; 92:1152-1164

8. Chen CH, Huang GT, Lee HS, Yang PM. Clinical impact of screening first - degree relatives of patients with hepatocellular carcinoma.J.Clin.Gastroenterology 1998; 27: 236-239 9. Donato F, Gelati V, Chiesa R, Albertini A, Bucella E, Boffetaa $P$, et al. A case control study on family history of liver cancer as a risk factor for hepatocellular carcinoma in North Italy. Brescia HCC Study Cancer Causes Control 1999; 10;417-421

10. Zhu ZZ, Cong WH, et al .a p53 polymorphism modifies the risk of hepatocellular carcinoma among non-carriers but not carriers of chronic hepatitis $B$ virus infection. Cancer 2005; 229:77-83.

11. Hang YM, Lu SC, Mato JM et al. Genetic polymorphisms in the methylentetrahydrofolate reductase and thymidylate syntethase genes and risk of hepatocellular carcinoma. Hepatology 2007; 46:749-758

12. Marrero JA, Fontane RJ, Lok As. NAFLD may be a common underlying liver disease in patients with hepatocellular carcinoma in the United States. Hepatology 2002; 36: 1349-1354

13. Yu M W, Yang YC, Lin SM, et al. Androgen receptor exon 1 CAG repeats length and risk of hepatocellular carcinoma in women. Hepatology 2002; 36:156-163.

14. Kasugai $H$, Yamamoto $R$, Tatsuta $M$, et al. Value of heparinized fine-needle aspiration biopsy in liver malignancy. AJR Am J Roentgenol 1985; 144:243-244

15. Peters RL. Pathology of hepatocellular carcinoma. In: Okuda K, Peters RL, eds. Hepatocellular carcinoma. New York: John Wiley, 1976:107-68
16. Kondo F, Ebara M, Sugiura $N$, et al. Histological features and clinical course of large regenerative nodules: evaluation of their precancerous potentiality . Hepatology 1990; 12:592-8

17. Gibson JB, Sobin LH. Histological typing of tumors of the liver, biliary tract and pancreas. International histological classification of tumours no. 20. Geneva: World Health Organization, 1978:12-30

18. Kaplan EL, Meier P. Nonparametric estimation from incomplete observations. J Am Stat Assoc 1958; 53:457481

19. Cox DR. Regression models and life-tables. J $R$ Stat Soc [B] 1972;34:187-220

20. Trichopoulos D, MacMahon B, Sparros L, Merikas G. Smoking and hepatitis $B$-negative primary hepatocellular carcinoma. J Natl Cancer Inst 1980;65:111-114

21. Oshima A, Tsukuma H, Hiyama T, Fujimoto I, Yamano H, Tanaka M. Follow-up study of HBs Ag-positive blood donors with special reference to effect of drinking and smoking on development of liver cancer. Int J Cancer 1984;34:775-779

22. Tsukuma H, Hiyama T, Oshima A, et al. A case-control study of hepatocellular carcinoma in Osaka, Japan. Int J Cancer 1990;45:231-236

23. Tanaka K, Hirohata T, Koga S, et al. Hepatitis $C$ and hepatitis $B$ in the etiology of hepatocellular carcinoma in the Japanese population. Cancer Res 1991;51:2842-2847

24. Yu M-W, You S-L, Chang A-S, Lu S-N, Liaw Y-F, Chen C-J. Association between hepatitis $C$ virus antibodies and hepatocellular carcinoma in Taiwan. Cancer Res 1991;51:5621-5625

25. Hirayama T. A large-scale cohort study on the relationship between diet and selected cancers of digestive organs. In: Bruce WR, Correa P, Lipkin $M$, Tannenbaum SR, Wilkins TD, eds. Gastrointestinal cancer: endogenous factors. Banbury report 7. Cold Spring Harbor, N.Y.: Cold Spring Harbor Laboratory, 1981:409-26.

26. Shibata A, Hirohata $T$, Toshima $H$, Tashiro $H$. The role of drinking and cigarette smoking in the excess deaths from liver cancer. Jpn J Cancer Res 1986; 77:287- 295 